\title{
Trapping Triatominae in Silvatic Habitats
}

\section{François Noireau $/ * /^{+}$, Fernando Abad-Franch**;,Sebastião AS Valente****;, Artur Dias-Lima ${ }^{* * * * * ;}$, Catarina M Lopes, Vanda Cunha, Vera C Valente ${ }^{* \ldots * *}$,

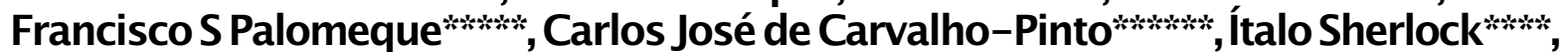

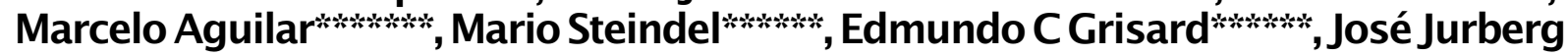

\begin{abstract}
Laboratório Nacional e Internacional de Referência em Taxonomia de Triatomíneos, Departamento de Entomologia, Instituto Oswaldo Cruz-Fiocruz, Av. Brasil 4365, 21045-900 Rio de Janeiro, RJ, Brasil *Institut de Recherche pour le Développement UR016, Paris, France **Pathogen Molecular Biology and Biochemistry Unit, Department of Infectious and Tropical Diseases, LSHTM, London, UK ***Instituto Evandro Chagas, Programa de Doença de Chagas, Ananindeua, PA, Brasil ****Centro de Pesquisa Gonçalo Moniz-Fiocruz, Salvador, BA, Brasil *****Departamento de Biología, Pontifícia Universidad Católica del

Ecuador, Quito, Ecuador ******Departamento de Microbiologia e Parasitologia, Universidade Federal de Santa Catarina,

Florianópolis, SC, Brasil *******Unidad de Medicina Tropical, Instituto Juan César García, Quito, Ecuador
\end{abstract}

Large-scale trials of a trapping system designed to collect silvatic Triatominae are reported. Live-baited adhesive traps were tested in various ecosystems and different triatomine habitats (arboreal and terrestrial). The trials were always successful, with a rate of positive habitats generally over $20 \%$ and reaching $48.4 \%$ for palm trees of the Amazon basin. Eleven species of Triatominae belonging to the three genera of public health importance (Triatoma, Rhodnius and Panstrongylus) were captured. This trapping system provides an effective way to detect the presence of triatomines in terrestrial and arboreal silvatic habitats and represents a promising tool for ecological studies. Various lines of research are contemplated to improve the performance of this trapping system.

Key words: Triatominae - trapping system - silvatic environment - terrestrial ecotopes - arboreal ecotopes

The control of domestic vector species of Triatominae is being successfully pursued in most of the Southern Cone countries and is being developed in the Andean countries and Central America. In areas with successful control programmes, report of silvatic species invading human dwellings leads research to be focused on their original habitats. Observations on the ecology and behaviour of these silvatic triatomines will assist in devising strategies for control-surveillance in areas where they invade or colonize synanthropic habitats (Schofield et al. 1999).

Understanding of the ecology and biology of Triatominae in their natural habitats is fragmentary, principally because collection of specimens is laborious and time-consuming. Light trapping may be effective in open vegetation, but only small numbers of starved adults of those species that are light-attracted can be captured. An alternative is meticulous "habitat dissection" of the great variety of potential ecotopes where triatomines breed, including hollow trees, palm tree crowns, bromeliads, rock piles, burrows, and bird-nests. The few animal-baited trapping devices previously designed to sample silvatic triatomines have yielded poor results (Rabinovich et al. 1976, Carcavallo 1985).

Recently, the use of a simple trapping system to collect silvatic triatomines was reported (Noireau et al. 1999, 2000).

Research supported by the CNPq, IRD, UNDP/World Bank/ WHO Special Programme for Research and Training in Tropical Diseases (grants 970195 and A00206), Fiocruz, Funasa, ECLAT network, the Cañada-Blanch Foundation and the University General Hospital (Valencia, Spain).

${ }^{+}$Corresponding author. Fax: +55-21-2573-4468. E-mail: noireauf@ioc.fiocruz.br

Received 8 May 2001

Accepted 16 August 2001
Here we present results of the first trials of this trapping system in various ecosystems and different triatomine habitats.

\section{MATERIALS AND METHODS}

The traps consisted of small plastic containers (250 or $500 \mathrm{~cm}^{3}$ ) closed with wire mesh and partially covered with double-sided adhesive tape (Figure). They contained a mouse as bait together with a small quantity of wood shavings and food. Initially designed for collecting silvatic Triatoma in hollow trees, the system was later applied to the capture and study of Rhodnius species in palm tree crowns (Abad-Franch et al. 2000, Palomeque et al. 2000, Valente et al. 2000).

This trapping system has now been tested in various ecosystems (Chaco, Caatinga, Amazon basin, and subtropical humid forests) and in four types of triatomine habitats (hardwood trees, palm trees, rock piles and crags). Traps were suspended in hollows located in trunks and limbs of hardwood trees, or were placed in the crown of palm trees, among rocks or inside crevices. One to four

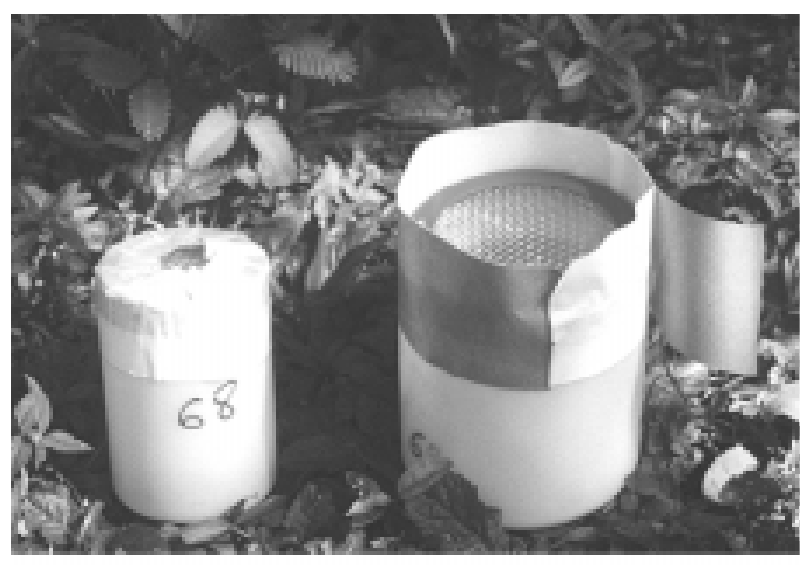

The trapping system 
traps were generally used for each site, depending on its dimensions and the number of accessible triatomine shelters (hollows in the case of trees). Four traps were usually set in each palm crown. Traps were commonly set in the afternoon and inspected the next morning, approximately $15 \mathrm{~h}$ later, in order to avoid the midday heat.

\section{RESULTS}

With the live-bait traps, some mouse mortality was recorded $(<2 \%)$. It was generally due to the attack by ants and is avoidable by covering the wire mesh with finer cloth. Results of the different capture series according to the ecosystem and triatomine habitat are shown in Table I. Trials performed in favourable habitats known to harbour triatomines were always successful, with a positivity rate higher than $20 \%$ and reaching $33.7 \%$ in hardwood trees in the Bolivian Chaco, $38.5 \%$ in rock piles of the Caatinga, and $48.4 \%$ in palm trees of the Ecuadorian Amazon basin. The apparent density of insects per positive habitat was highest for palm trees in the Amazon basin and West Andean foothills in Ecuador (12.5 and 10.2, respectively), and reached 6.8 in rock piles. Eleven species of Triatominae (six Triatoma, four Rhodnius, and one Panstrongylus species) have been captured with this method (Table I).

Results on the efficacy of the trapping system are shown in Table II. The positivity rate of traps was higher in palm crowns and rock crevices than in hollow trees. The number of insects adhered to the tape was usually low (one or two insects) but could reach high densities (> 10, and up to 51) in some palm tree crowns.

\section{DISCUSSION}

The increasing reports of silvatic triatomine species invading (and sometimes colonizing) peridomestic and domestic habitats endorse the need for research on their original wild populations and habitats. The study of these habitats by means of traditional approaches (random manual searches and dissection) is laborious and destructive, hampering the development of more detailed studies. Hence, many of the characteristics of triatomine habitats are often obscure and remain to be more thoroughly investigated (Romaña et al. 1999, Gaunt \& Miles 2000). Livebaited adhesive traps could help overcome some of these problems.

TABLE I

Positive habitats and species of Triatominae collected

\begin{tabular}{|c|c|c|c|c|c|}
\hline Study area & Habitat & $\begin{array}{l}\text { No. of habitats } \\
\text { surveyed } \\
(\% \text { positive })\end{array}$ & $\begin{array}{l}\text { Mean no. (SD) } \\
\text { of insects by } \\
\text { positive habitat }\end{array}$ & $\begin{array}{l}\text { Range of } \\
\text { density }\end{array}$ & $\begin{array}{l}\text { Species of } \\
\text { Triatominae collected }\end{array}$ \\
\hline Chaco (Bol) & Hardwood trees ${ }^{a}$ & $421(33.7)$ & $1.9(1.4)$ & $1-12$ & $\begin{array}{l}\text { Triatoma sordida } \\
\text { T. guasayana } \\
\text { T. infestans (dark morph) }\end{array}$ \\
\hline Caatinga (Bra) & Hardwood trees $b$ & $67(17.9)$ & $1.9(1.2)$ & $1-6$ & T. pseudomaculata \\
\hline East Andean foothills (Bol) & Hardwood trees & $14(21.4)$ & $2.0(0.7)$ & $1-3$ & Panstrongylus megistus \\
\hline Caatinga (Bra) & Rock piles & $13(38.5)$ & $6.8(3.8)$ & $3-13$ & T. brasiliensis \\
\hline Serra Geral (Bra) & Crags & $10(20)$ & $1.5(0.8)$ & $1-4$ & T. klugi \\
\hline Caatinga (Bra) & Palm trees ${ }^{c}$ & $59(10.2)$ & $1.8(1.4)$ & $1-6$ & Rhodnius nasutus \\
\hline Amazon basin (Bra) & Palm trees $d$ & $53(22.6)$ & $2.5(2.1)$ & $1-14$ & $\begin{array}{l}R . \text { pictipes } \\
R . \text { robustus }\end{array}$ \\
\hline Amazon basin $(\mathrm{Ecu})$ & Palm trees ${ }^{e}$ & $64(48.4)$ & $12.5(18.7)^{g}$ & $1-98^{g}$ & $\begin{array}{l}R . \text { pictipes } \\
R \text {. robustus }\end{array}$ \\
\hline West Andean foothills (Ecu) & Palm trees $f$ & $56(25)$ & $10.2(4.9)$ & $3-22$ & R. ecuadoriensis \\
\hline Central coast lowlands (Ecu) & Palm trees $f$ & $16(6.2)$ & Only 1 bug captured & - & R. ecuadoriensis \\
\hline Coastal area $(\mathrm{Ecu})$ & Palm trees $f$ & $36(27.8)$ & $3.0(2.6)$ & $1-9$ & R. ecuadoriensis \\
\hline
\end{tabular}

a: dominated by Ruprechtia triflora; $b$ : Caesalpinia pyramidalis, Spondias tuberosa, Bumelia sartorum, Anadenanthera colubrina and Astronium urundeuva resulted positive; $c$ : Copernicia prunifera; $d$ : dominated by Attalea regia and A. speciosa; : Attalea, Phytelephas, Astrocaryum, Oenocarpus and Elaeis resulted positive; $f$ : dominated by $P$. aequatorialis (palma de tágua); $g$ : combining traps and manual capture on palm crowns; Bol: Bolivia; Ecu: Ecuador; Bra: Brazil

TABLE II

Efficacy of the trapping system

\begin{tabular}{|c|c|c|c|c|}
\hline Study area & Ecotope & $\begin{array}{l}\text { Traps placed } \\
(\% \text { positive })\end{array}$ & $\begin{array}{l}\text { Mean no. (SD) of insects } \\
\text { by positive traps }\end{array}$ & Range of density \\
\hline Chaco (Bol) & Hollow trees & $732(21.9)$ & $1.7(1.0)$ & $1-8$ \\
\hline Caatinga (Bra) & Hollow trees & 78 (17.9) & $1.5(0.7)$ & $1-3$ \\
\hline East Andean foothills (Bol) & Hollow trees & $27(18.5)$ & $1.2(0.3)$ & $1-2$ \\
\hline Caatinga (Bra) & Rock crevices & $29(27.6)$ & $3.4(1.6)$ & $1-7$ \\
\hline Serra Geral (Bra) & Crag crevices & $60(21.6)$ & $1.5(0.8)$ & $1-4$ \\
\hline West Andean foothills (Ecu) & Palm trees & $88(32.9)$ & $4.9(3.4)$ & $1-14$ \\
\hline Central coast lowlands (Ecu) & Palm trees & $43(2.3)$ & $a$ & - \\
\hline Coastal area $(\mathrm{Ecu})$ & Palm trees & $91(16.5)$ & $1.9(1.3)$ & $1-6$ \\
\hline Amazon basin $(\mathrm{Ecu})$ & Palm trees & $111(43.2)$ & $5.2(9.1)$ & $1-51$ \\
\hline Caatinga (Bra) & Palm trees & $59(10.2)$ & $1.8(1.4)$ & $1-6$ \\
\hline Amazon basin (Bra) & Palm trees & $72(19.4)$ & $1.7(1.2)$ & $1-9$ \\
\hline
\end{tabular}

Bol: Bolivia; Ecu: Ecuador; Bra: Brazil; $a$ : only 1 bug captured. 
Results of several independent studies presented here suggest live-baited trapping provides a quick, simple and inexpensive way to detect the presence of triatomine populations in silvatic habitats. Four important triatomine ecotopes were successfully searched by this method. Other terrestrial (burrows, bromeliads, tree root cavities) and arboreal habitats (bromeliad epiphytes) remain to be investigated. Eleven species of Triatominae were captured in various environments, suggesting that the system may be applied to other species as well. Repeated series of captures in positive habitats increased the number of bugs captured, allowing for a more accurate assessment of the density of colonies. Starved bugs were more likely to be attracted by the bait; thus, the proportion of bugs captured in each ecotope would be inversely correlated to the nutritional status of the population. This study confirms that the nutritional status of silvatic bugs is generally very poor and may explain the unsuccessful results obtained by live-baited trapping in domestic habitat where triatomines are commonly fed (Tonn et al. 1976, Noireau \& Dujardin 2001). Using this trapping system, the ecological (and economical) damage caused by felling and dissecting trees to study associated triatomines may be avoided. With regard to the capture of $T$. klugi in crag crevices, previous attempts using light trapping and active searching in crevices were unsuccessful.

Live-baited adhesive traps represent a promising tool to identify triatomine habitats that may thereafter be studied longitudinally (including for instance the response of bug populations to variations in microclimatic conditions or hosts, or to biological control interventions). By allowing the capture of silvatic specimens, several entomological factors can be investigated (e.g. geographic range, density and structuring of bug populations or species, natural infection by trypanosomes etc.). Furthermore, our knowledge on the ecology of these populations (association to specific habitats, behavioural differences in relation to vertebrate hosts etc.) may benefit from this sampling technique. Live-baited traps may help define "highrisk" ecotopes (e.g., containing dense bug colonies of species displaying synanthropic behaviour and frequently infected by Trypanosoma cruzi) nearby human dwellings, an important issue in areas where invasion and re-infestation of houses by silvatic vectors hinder long-term interruption of vector-borne transmission.

Various lines of research could be explored to improve the performance of this trapping system. Replacement of the live bait by a chemical attractant would make traps easier to handle in the field, and could help reduce their size so that smaller ecotopes (hollow trees and rock crevices) might be studied. Finally, the design of a trapping system for intra- and peridomestic habitats could be of use for entomological vigilance after control interventions.

\section{ACKNOWLEDGEMENTS}

To Michael A Miles for the revision of an earlier version of the manuscript. To Teresa Gutierrez, Rosmary Flores, José Luis Botetano, Carlos Carpio, Karyna Suárez, José Elson Abud de Araújo, Carlos Alberto Rodrigues, Gilberto César Rodrigues and Nélio do Nascimento Farias for their invaluable assistance in the field work. To Laure Emperaire for reviewing the identification of trees and CJ Schofield for the useful comments on the manuscript.

\section{REFERENCES}

Abad-Franch F, Noireau F, Paucar A, Aguilar M, Carpio C, Racines J 2000. The use of live bait traps for the study of sylvatic Rhodnius populations (Hemiptera: Reduviidae) in palm trees. Trans R Soc Trop Med Hyg 94: 629-630.

Carcavallo RU 1985. Técnicas de estudio de triatominos en ambiente silvestre. In RU Carcavallo, JE Rabinovich, RJ Tonn (eds), Factores Biológicos y Ecológicos en la Enfermedad de Chagas, vol. 1, OPS-ECO/MSAS-SNCH, Buenos Aires, p. 49-52.

Gaunt M, Miles M 2000. The ecotopes and evolution of triatomine bugs (Triatominae) and their associated trypanosomes. Mem Inst Oswaldo Cruz, 95: 557-565.

Noireau F, Dujardin JP 2001. Flight and nutritionnal status of sylvatic Triatoma sordida and T. guasayana. Mem Inst Oswaldo Cruz 96: 385-389.

Noireau F, Flores R, Vargas F 1999. Trapping sylvatic Triatominae (Reduviidae) in hollow trees. Trans R Soc Trop Med Hyg 93: 13-14.

Noireau F, Flores R, Gutierrez T, Abad-Franch F, Flores E, Vargas F 2000. Natural ecotopes of Triatoma infestans dark morph and other sylvatic triatomines in the Bolivian Chaco. Trans $R$ Soc Trop Med Hyg 94: 23-27.

Palomeque FS, Abad-Franch F, Suárez K, Aguilar VHM 2000. Uso de trampas con cebo vivo para el estudio de poblaciones silvestres de Rhodnius (Reduviidae: Triatominae) en palmeras de la Amazonia ecuatoriana. Memorias, XXIV Jornadas Ecuatorianas de Biología, p. 108.

Rabinovich JE, Carcavallo RU, Barretto MP 1976. Ecologic methods: marking, trapping, and sampling for vector studies in the field. In New Approaches in American Trypanosomiasis Research, PAHO scientific publication 318, Washington, p. 16-20.

Romaña C, Pizzaro NJC, Rodas E, Guilbert E 1999. Palm trees as ecological indicators of risk areas for Chagas disease. Trans $R$ Soc Trop Med Hyg 93: 594-595.

Schofield CJ, Diotaiuti L, Dujardin JP 1999. The process of domestication in Triatominae. Mem Inst Oswaldo Cruz 94 (Suppl. 1): 375-378.

Tonn RJ, Otero MA, Jiménez J 1976. Comparación del método hora-hombre con la trampa Gómez-Núñez en la búsqueda de Rhodnius prolixus. Bol Dir Malar Saneam Ambiental 16: 269-275.

Valente VC, Valente SAS, Rodrigues CA, Souza GCR, Noireau F, Lopes CM, Cunha V 2000. Estudo preliminar da eficiência de captura de triatomíneos silvestres utilizando armadilhas com fita adesiva em Bragança, Pará. Rev Soc Bras Med Trop 33 (Suppl. 2): 94-95. 
